7. Reprod. Fert. (1971) 27, 311-320

\title{
AUTOIMMUNE ORCHITIS INDUCED BY AUTOIMMUNIZATION WITH SEMINAL PLASMA IN THE RABBIT
}

\author{
C. YANTORNO, MARIA T. DEBANNE AND ELSA VOTTERO-CIMA
}

Cátedra de Inmunología y Cátedra de Química Clínica, Departamento de Bioquímica Clinica, Facultad de Ciencias Químicas, Universidad Nacional de Córdoba, ${ }^{*}$ Argentina

(Received 2nd September 1970, revised 19th April 1971)

\begin{abstract}
Summary. Intensive autoimmunization of rabbits with native or chemically modified seminal plasma incorporated with complete Freund's adjuvant induces autoantibodies against the homologous material as well as against testicular antigens. Testicular lesions were observed in most animals. When accessory gland extract was used as the immunizing material, repeated injections failed to induce antitesticular antibodies or to cause testicular damage. Semen analysis during treatment showed the presence of immature cells from the seminiferous epithelium. The experimentally induced condition developed in this work satisfies the definition of allergic orchitis.
\end{abstract}

\section{INTRODUCTION}

Allergic orchitis is one of the best examples of experimentally induced autoimmune disease. Following the first report by Voisin, Delaunay \& Barber (1951) on the subject, Freund, Lipton \& Thompson (1953) firmly established the main features of this disease in guinea-pigs. It was proved later that the reaction may be easily evoked in rat (Freund, Lipton \& Thompson, 1954), mouse (Pokorná, Vojtiśková, Rychlíková \& Chutná, 1963), quail (Wentworth \& Mellen, 1964), man (Mancini, Andrada, Saraceni, Bachmann, Lavieri \& Nemirovsky, 1965) and monkey (Andrada, Andrada \& Witebsky, 1969) by heterologous, homologous or autologous testicular homogenates from mature individuals when combined with Freund's complete adjuvant.

The failure of rabbits to show allergic orchitis, reported by Weil \& Finkler (1959) and Stevens \& Fost (1964), is a controversial point in this field of experimental autoimmunity. The purpose of the present study was to attempt to induce allergic orchitis in rabbits. Testicular materials are generally used as a source of antigens for this purpose, although Vulchanov (1969) has shown that immunization with seminal plasma will induce allergic orchitis in guineapigs.

* Postal address: Laboratorio Central, Hospital Nacional de Clínicas, Santa Rosa 1564, Córdoba, Rep. Argentina. 


\section{MATERIALS AND METHODS}

Experimental animals

Seventeen, adult, male rabbits from our closed colony which originated from crossbred Flemish Giant and New Zealand rabbits, weighing 4 to $5 \mathrm{~kg}$, were used.

\section{Antigens}

Saline extracts of all specimens of tissues used were prepared as described previously (Shulman, Yantorno, Soanes, Gonder \& Witebsky, 1966).

Native seminal plasma was obtained from rabbits by means of the artificial vagina described by Bredderman, Foote \& Yassen (1964). Samples were centrifuged at $12,300 \times 15 \mathrm{~g} / \mathrm{min}$ at $4^{\circ} \mathrm{C}$, immediately after collection, in order to obtain the seminal plasma. Pooled material was prepared using several individual samples. These preparations were stored at $-18^{\circ} \mathrm{G}$ until required.

Chemically modified seminal plasma preparations were used, in which the proteins of the rabbit seminal plasma were coupled to diazonium derivatives of sulphanilic and arsanilic acid following the procedure described by Campbell, Garvey, Cremer \& Sussdorf (1964). To obtain the diazonium derivatives for the conjugate, a total of $0.1 \mathrm{~g}$ rabbit seminal plasma proteins, $0.0865 \mathrm{~g}$ sulphanilic acid and $0 \cdot 1085 \mathrm{~g}$ arsanilic acid was employed.

\section{Immunization}

Volumes $(0.5 \mathrm{ml})$ of antigenic material containing $10 \mathrm{mg}$ of protein were injected at 0,30 and 50 days into the shaved back of the experimental animals. The antigenic material was emulsified in an equal volume of Freund's complete adjuvant for the first two injections. The third injection was applied after fortifying the adjuvant with $8 \mathrm{mg}$ of $M$. tuberculosis/ml. Bleedings were obtained before every injection and at various intervals during the immunizing period.

Rabbits were separated into three experimental groups.

Group I. Animals from this group were immunized with native autologous seminal plasma. Rabbits 134 and 135 received a total of $60 \mathrm{mg}$ protein, and Rabbits 126 and 137, a total of $30 \mathrm{mg}$. Rabbits 109, 111, 113 and 115 received an additional injection of $10 \mathrm{mg}$ protein on Day 15.

Group II. The antigen used in this group was chemically modified rabbit seminal plasma. A total of $30 \mathrm{mg}$ protein was injected. The animals employed were coded 107, 110, 140 (autoimmunized) and 122, 127 (isoimmunized).

Group III. Four animals, coded 141, 142, 145 and 178, were intradermally isoimmunized with extracts of rabbit male accessory glands. Each animal received a total of $30 \mathrm{mg}$ protein. Two other animals, 108 and 118, received an intensive sensitization with human haemoglobin, the course of injections following the general schedule of immunization.

\section{Immunological assays}

Direct passive haemagglutination. This technique was performed according to the method of Boyden (1951) as modified by Yantorno, Soanes, Gonder \& Shulman (1967). Native rabbit seminal plasma or testicular extract at $0.1 \mathrm{~g} \%$ protein concentration was used as coating material. 
Complement fixation test. The test was carried out according to the method of Kolmer (1928). Testicular extract at a $1 / 50$ dilution, containing $26 \mathrm{mg} \%$ protein, was used as antigen.

Sperm immobilization test. The sperm suspension was obtained at autopsy from the epididymis of a mature buck. After carefully dissecting out the epididymis and cutting it into small fragments, the spermatozoa were suspended in $0.4 \%$ fructose-buffered solution to obtain a concentration of $1 \times 10^{6}$ spermatozoa $/ \mathrm{ml}$. Optimal complement dilution was determined for each sperm suspension, and usually varied between $1 / 3$ to $1 / 10$. To $0 \cdot 1 \mathrm{ml}$ of a threefold serial dilution of inactivated serum were added $0.1 \mathrm{ml}$ guinea-pig complement dilution and $0.1 \mathrm{ml}$ sperm suspension. After incubation at $37^{\circ} \mathrm{C}$, the percentage of active spermatozoa was estimated. Serum samples obtained before and after treatment were assayed simultaneously under identical experimental conditions. The result was considered positive when sperm motility in serum after treatment was less than $25 \%$, taking sperm motility in the serum before treatment as $100 \%$.

Immunodiffusion. This method was based on that of Ouchterlony (1958), using $1.5 \%$ agar (Bacto-Agar Difco) in $0.15 \mathrm{M}-\mathrm{NaCl}$, with $1 / 10,000$ merthiolate as a preservative.

Skin test. Antigenic material $(0 \cdot 1-\mathrm{ml}$ vols containing approximately $2 \mathrm{mg}$ of protein) was injected intradermally into the shaved area of the back. The response was assessed $24 \mathrm{hr}$ later.

\section{Cytomorphological semen studies}

The number, vitality and motility of spermatozoa were determined on each semen sample by conventional procedures. Cytomorphological changes were studied on slides stained according to the Papanicolaou (E.A. 36) (1954) and May Grünwald-Giemsa methods.

\section{Histological studies}

Testes were removed at varying intervals of time after injection. The specimens were fixed immediately in Steave's fluid and processed, employing conventional histological procedures which included embedding in paraffin wax and sectioning at $7 \mu \mathrm{m}$. The sections were stained with PAS-haematoxylin.

Histological interpretation of the testicular biopsies was based upon a rating scale in which ascending numerals indicate increasing order of damage in a manner similar to that utilized by Freund et al. (1954).

\section{RESULTS}

Normality and maturity of experimental animals

Semen parameters of rabbits from our colony were previously determined. The average ejaculate volume, without gel-mass, was $0.79 \mathrm{ml} \pm 0.29$. The mean sperm concentration per $\mathrm{ml}$ was $226 \pm 92 \times 10^{6}$, vitality $91 \% \pm 8$ and motility $88 \% \pm 10$. The proportion of abnormal forms, mainly decapitated spermatozoa, coiled tails and deformed heads, was less than $0.3 \%$. The normality and 
maturity of the experimental animals was then established before treatment. A wide range of variation was observed in sperm counting although oligospermia (less than $20 \times 10^{6}$ spermatozoa $/ \mathrm{ml}$ ) was never observed in these animals before treatment. As a further control, Rabbits 135, 137, 140 and 145, representing each of the four groups, were submitted to hemicastration for histological control. This treatment does not affect the spermatogenesis of the contralateral testis (Swierstra, Whitefield \& Foote, 1964).

\section{Semen studies during treatment}

Semen studies were performed for all experimental animals at variable intervals. In some cases, semen samples were analysed daily over a short period of time, but generally such studies were carried out every 4 or 5 days.

TABLE 1

MAIN FEATURES OF RABBIT SEMEN STUDIES AND DEGREE OF TESTIGULAR LESION DURING TREATMENT

\begin{tabular}{|c|c|c|c|c|c|c|c|}
\hline \multirow{2}{*}{$\underset{\text { group }}{\operatorname{Exp}}$} & \multirow{2}{*}{$\begin{array}{l}\text { Rabbit } \\
\text { no. }\end{array}$} & \multicolumn{5}{|c|}{ Semen analysis } & \multirow{2}{*}{$\begin{array}{l}\text { Degree } \\
\text { of } \\
\text { testicular } \\
\text { lesion }\end{array}$} \\
\hline & & $\begin{array}{l}\text { No. of } \\
\text { analyses }\end{array}$ & Spermatocytes & Spermatids & $\begin{array}{l}\text { Sperm } \\
\text { count }\end{array}$ & $\begin{array}{l}\text { Maximum ratio of } \\
\text { spermatids/sperm. } \\
\text { in semen }\end{array}$ & \\
\hline \multirow[t]{5}{*}{ I } & 109 & 12 & Occasional & Occasional & $\begin{array}{l}\text { Occasional } \\
\text { oligospermia }\end{array}$ & 6 & II \\
\hline & 111 & 12 & Occasional & Frequent & $\begin{array}{l}\text { Azoospermia } \\
\text { at the end of } \\
\text { treatment }\end{array}$ & $\infty$ & IV \\
\hline & $\begin{array}{l}113 \\
115\end{array}$ & $\begin{array}{l}14 \\
14\end{array}$ & $\begin{array}{l}\text { Occasional } \\
\text { Occasional }\end{array}$ & $\begin{array}{l}\text { Frequent } \\
\text { Frequent }\end{array}$ & $\begin{array}{l}\text { Normospermia } \\
\text { Normospermia }\end{array}$ & $\begin{array}{l}1 \\
1\end{array}$ & III \\
\hline & 134 & 16 & Not observed & Not observed & Normospermia & $<0.01$ & \\
\hline & & & Not observed & Occasional & $\begin{array}{l}\text { Occasional } \\
\text { oligospermia }\end{array}$ & $0 \cdot 1$ & Minima \\
\hline \multirow[t]{2}{*}{ II } & $\begin{array}{l}107 \\
110\end{array}$ & $\begin{array}{l}17 \\
17\end{array}$ & $\begin{array}{l}\text { Occasional } \\
\text { Occasional }\end{array}$ & $\begin{array}{l}\text { Frequent } \\
\text { Frequent }\end{array}$ & $\begin{array}{l}\text { Normospermia } \\
\text { Occasional }\end{array}$ & $\begin{array}{l}0.4 \\
0 \cdot 8\end{array}$ & $\begin{array}{l}\text { II } \\
\text { III }\end{array}$ \\
\hline & $\begin{array}{l}122 \\
127\end{array}$ & $\begin{array}{l}13 \\
13\end{array}$ & $\begin{array}{l}\text { Not observed } \\
\text { Not observed }\end{array}$ & $\begin{array}{l}\text { Uncommon } \\
\text { Occasional }\end{array}$ & $\begin{array}{l}\text { Normospermia } \\
\text { Occasional } \\
\text { oligospermia }\end{array}$ & $\begin{array}{l}0 \cdot 1 \\
0 \cdot 4\end{array}$ & $\begin{array}{l}\text { II } \\
\text { III }\end{array}$ \\
\hline III & $\begin{array}{l}141 \\
142 \\
145 \\
178\end{array}$ & $\begin{array}{l}19 \\
21 \\
20 \\
14\end{array}$ & $\begin{array}{l}\text { Not observed } \\
\text { Not observed } \\
\text { Not observed } \\
\text { Not observed }\end{array}$ & $\begin{array}{l}\text { Not observed } \\
\text { Not observed } \\
\text { Not observed } \\
\text { Not observed }\end{array}$ & $\begin{array}{l}\text { Normospermia } \\
\text { Normospermia } \\
\text { Normospermia } \\
\text { Normospermia }\end{array}$ & $\begin{array}{l}<0.01 \\
<0.01 \\
<0.01 \\
<0.01\end{array}$ & $\begin{array}{l}0 \\
0 \\
0 \\
0\end{array}$ \\
\hline
\end{tabular}

The main features of the semen analyses during treatment are summarized in Table 1 and the results are compared with the degree of damage observed in the testes. A testicular lesion was invariably correlated with the presence of spermatids in the semen. These cells could be present in large numbers and showed various cytomorphological alterations such as hyperchromasia, pycnosis and multinucleation. The presence of spermatocytes appeared to indicate severe testicular damage. On the other hand, semen samples from rabbits showing definite testicular injury showed no significant change in sperm 
number, motility or viability during the whole period of treatment. Since the characteristic lesion of intermediate degree observed in our experimental groups was heterogeneously distributed, it is believed that a few tubules can suffice to produce a normal amount of spermatozoa. Macrophages were never observed in semen samples from these animals.

\section{Histological studies}

An overall view of the pathological findings in the testes of rabbits could be summarized as follows.

When injury was severe, spermatogenic arrest, loss of weight of the gonads and reduction of tubular diameter were invariably observed. In Rabbit 111, spermatogenesis was arrested at the spermatogonial stage and the tubules were almost depleted except for spermatogonia and Sertoli cells (see Pl. 1, Fig. 2). Histological specimens from Rabbits 110, 113, 115 and 127 showed a lesser degree of damage although spermatogenesis had not progressed beyond the spermatocyte stage in most tubules. Desquamation and pycnosis of the elements of the seminiferous epithelium and formation of multinucleated giant cells was frequently observed in the lumen of the tubules. Cytomorphological alterations were prominent and frequently observed in cases of moderate injury (Pl. 1, Figs. 3 and 4). The explanation for this may lie in the fact that spermatid changes are more easily detected. One of the most interesting observations was the absence of a consistent point of arrest in spermatogenesis. In some cases, this was a striking feature and caused marked alteration in the distribution pattern of the stages. Rabbits 109 and 107, for example, presented complete absence of several stages.

In a few animals, the damage to spermatogenesis was much less pronounced than in the cases already described although the injury was quite obvious as judged by the reduced number of tubules with mature spermatozoa. In these moderately advanced stages, the distribution of the damage was patchy and the degree of pathological findings varied considerably in the tubules. The vacuolated Sertoli cells did not show signs of phagocytic activity for the germinal cells but appeared to fill the tubules when the destruction of the germinal epithelium was pronounced.

Leydig cells were either unaffected or appeared hyperplastic. Interstitial infiltration and thickening of basement membrane were only observed in sections from Rabbits 110 and 111, which, after a careful search, revealed a few mononuclear cells scattered in the interstitium.

Among the animals showing testicular lesions in this group, some cases of minimal injury were recorded. Rabbits 135 and 140 showed marked depletion of different germ cell elements. Damage was selective since some spermatic tubules presented depletion of a whole generation whereas the interstitium was apparently unaffected.

Testes from Rabbits 141, 142, 145 and 178, isoimmunized with accessory gland extract, presented typical adult features with successive stages of transformation of the seminiferous epithelium. Normal testicular histology was retained in two other animals, 108 and 118 , even after intensive sensitization with human haemoglobin following the general schedule of immunization. 


\section{Immunological studies}

In order to detect and measure the immune response, several techniques were applied: direct passive haemagglutination, complement fixation, sperm immobilization, immunodiffusion and the skin test. Direct agglutination of sperm suspensions appeared to give highly variable results and, therefore, was not used in the present study.

Several serum samples from each animal were subjected to serological assays. Positive results were generally found using sera obtained after the third injection. The results are summarized in Table 2. It can be seen that most serum samples from rabbits immunized with native seminal plasma and all sera from the other two groups showed haemagglutinating activity against red

TABLE 2

SUMMARY OF SEROLOGICAL REAGTIONS PERFORMED WITH RABBIT SERA OBTAINED AFTER THE THIRD ANTIGEN INJEGTION

\begin{tabular}{|c|c|c|c|c|c|}
\hline \multirow[b]{2}{*}{ Group Rabbit } & \multirow[b]{2}{*}{ No. } & \multicolumn{4}{|c|}{ Serological studies and antigenic material } \\
\hline & & $\begin{array}{l}\text { Tanned red cell } \\
\text { agglutination. } \\
\text { Rabbit seminal } \\
\text { plasma }\end{array}$ & $\begin{array}{l}\text { Complement } \\
\text { fxation. } \\
\text { Testicular } \\
\text { extract }\end{array}$ & $\begin{array}{c}\text { Immunodiffusion. } \\
\text { Testicular } \\
\text { extract }\end{array}$ & $\begin{array}{c}\text { Sperm } \\
\text { immobilization. } \\
\text { Epididymal rabbit } \\
\text { spermatozoa }\end{array}$ \\
\hline $\begin{array}{l}\text { I. Immunized } \\
\text { with seminal } \\
\text { plasma }\end{array}$ & $\begin{array}{l}109 \\
111 \\
113 \\
115 \\
134 \\
135\end{array}$ & $\begin{array}{r}128 \\
<8 \\
1024 \\
<8 \\
8192 \\
1024\end{array}$ & $\begin{array}{r}<8 \\
<8 \\
8 \\
32 \\
16 \\
<8\end{array}$ & $\begin{array}{l}- \\
+ \\
+ \\
+ \\
-\end{array}$ & $\begin{array}{r}<3 \\
27 \\
3 \\
<3 \\
243 \\
81 \dagger\end{array}$ \\
\hline $\begin{array}{l}\text { II. Immunized } \\
\text { with modified } \\
\text { seminal } \\
\text { plasma }\end{array}$ & $\begin{array}{l}107 \\
110 \\
122 \\
127\end{array}$ & $\begin{array}{r}32768 \\
16384 \\
65536 \\
4096\end{array}$ & $\begin{array}{r}<8 \\
16 \\
8 \\
*\end{array}$ & $\begin{array}{l}+ \\
+ \\
+ \\
+\end{array}$ & $\begin{array}{r}27 \\
3 \\
81 \\
81\end{array}$ \\
\hline $\begin{array}{l}\text { III. Immunized } \\
\text { with rabbit } \\
\text { male accessory } \\
\text { gland }\end{array}$ & $\begin{array}{r}141 \\
142 \\
145 \\
178\end{array}$ & $\begin{array}{l}512 \\
256 \\
128 \\
512\end{array}$ & $\begin{array}{l}<8 \\
<8 \\
<8 \\
<8\end{array}$ & $\begin{array}{l}\cdots \\
- \\
-\end{array}$ & $\begin{array}{l}<3 \\
<3 \\
<3 \\
<3\end{array}$ \\
\hline
\end{tabular}

cells sensitized with rabbit seminal plasma, although titres were markedly higher in sera from rabbits immunized with chemically modified seminal plasma. When testicular extract was used as sensitizer material, all the sera gave negative results.

On the other hand, in sera from most rabbits immunized with either preparation of seminal plasma, antibodies against testicular extract were demonstrated by complement fixation and immunodiffusion. Likewise, sperm-immobilizing activity was found in sera from animals of both groups. By contrast, none of the animals immunized with accessory sex gland material showed antibodies against testicular antigens or sperm-immobilizing activity in their sera.

The autoantibody nature of the response was proven by haemagglutination 
PLATE 1
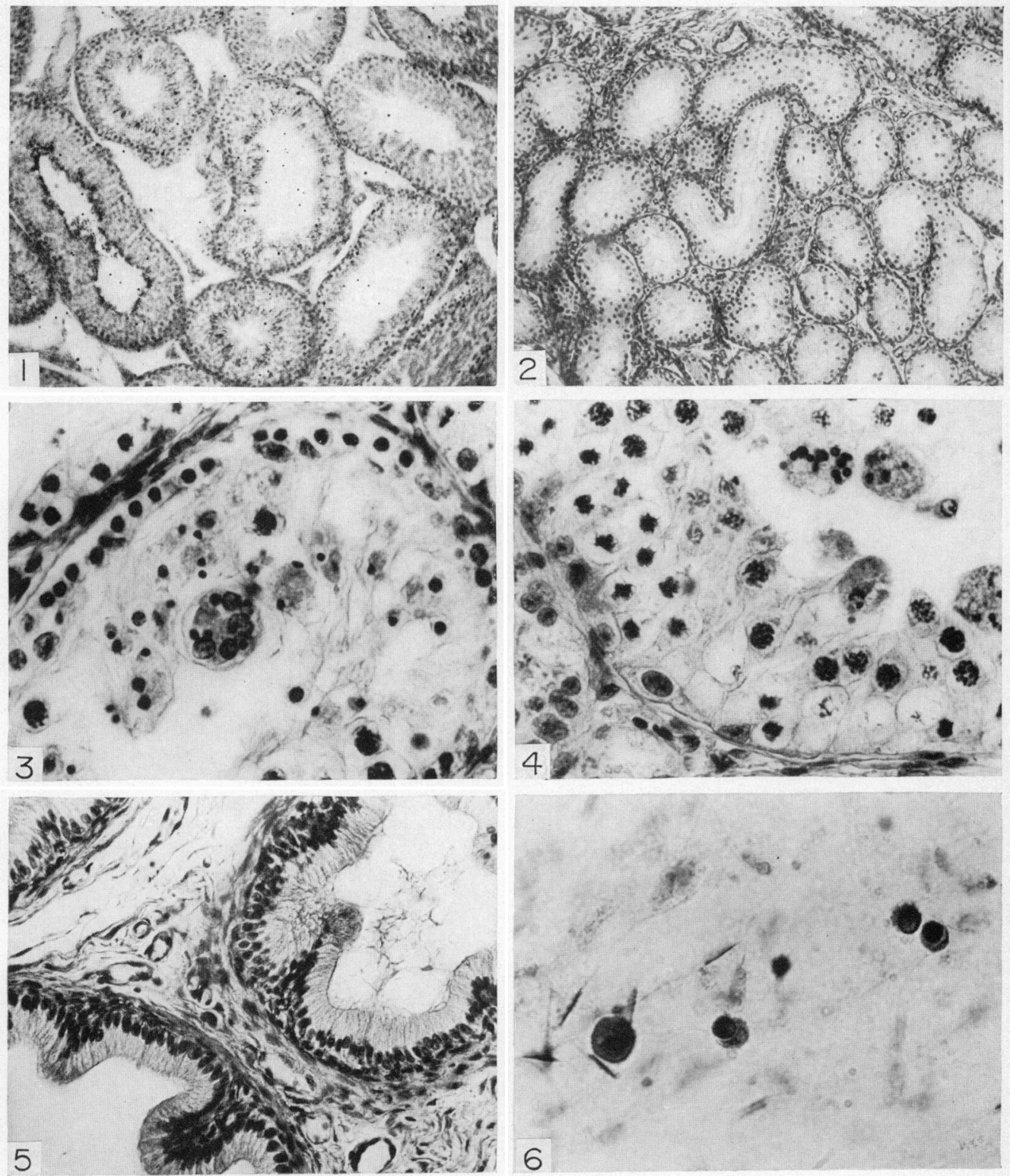

Fig. 1. Section of testis from Rabbit 145 immunized with extract of rabbit male accessory glands, showing normal features. PAS-haematoxylin, $\times 40$.

FIg. 2. Section of testis from Rabbit 111 immunized with rabbit seminal plasma. Reduction of tubular diameter and spermatogenic arrest are cvident. PAS-haematoxylin, $\times 40$.

Fig. 3. Marked depletion of germinal clements in histological specimen from Rabbit 109 immunized with rabbit seminal plasma. PAS-haematoxylin, $\times 360$.

FIs. 4. Desquamation, pycnosis and multinucleation of seminiferous epithelial elements in section of testis from Rabbit 122 immunized with chemically modified rabbit seminal plasma. PAS-hacmatoxylin, $\times 360$.

FIG. 5. Section of epididymis from Rabbit 109 showing lack of spermatozoa in the lumen. PAS-haematoxylin, $\times 180$.

FIG. 6. Immature seminiferous epithelial cells in semen from Rabbit 109. Papanicolaou stain, $\times 360$.

(Facing 1. 316) 


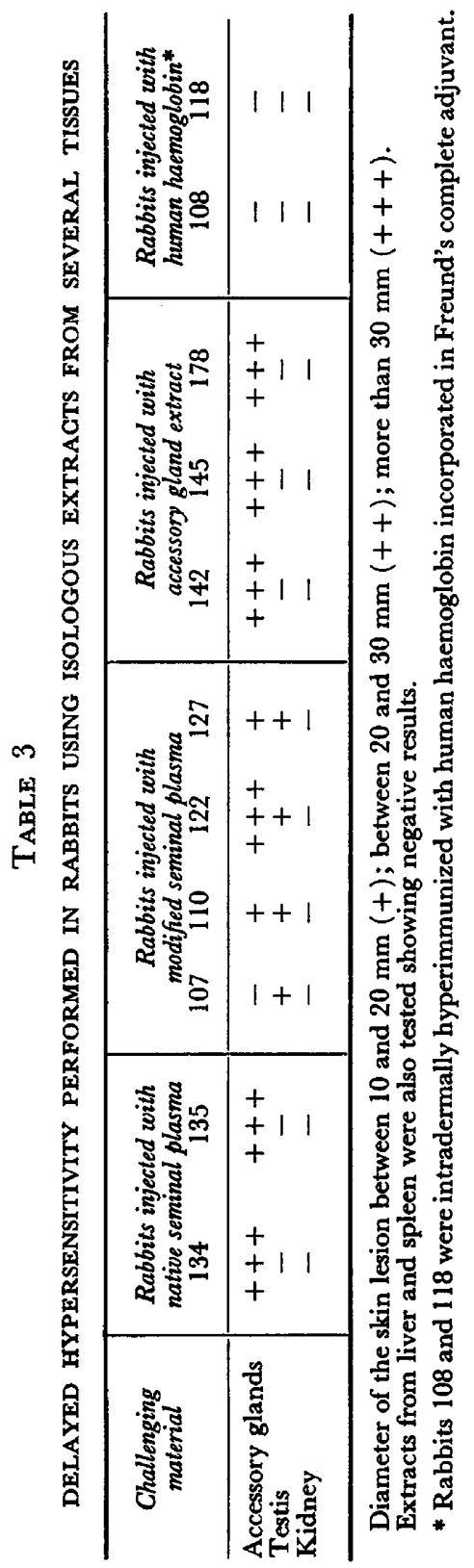


through the reaction of sera from Rabbits 107, 110, 122, 127 and 134 with tanned red cells coated with autologous seminal plasma.

It was found that the majority of rabbits from the three groups exhibited positive delayed skin hypersensitivity to isologous accessory gland extract (Table 3). Only animals from the group immunized with modified seminal plasma showed reactivity against testicular extracts. In general, these reactions were weaker compared with that produced using accessory gland material. When spleen, kidney and liver extracts were used as the challenging material, the results were negative in all cases. An additional specificity control was provided by Rabbits 108 and 118 which showed a negative skin reaction to all the tissue extracts used.

\section{DISCUSSION}

Intensive auto- or isoimmunization of rabbits with native or chemically modified seminal plasma incorporated with Freund's adjuvant has been shown to induce autoantibodies against the homologous material as well as against testicular antigens. A variety of lesions was observed in the testes from most animals. When seminal plasma was replaced by accessory gland extract as the immunizing material, repeated injections failed to evoke antitesticular immunity and to cause impairment of spermatogenesis, though anti-seminal plasma antibodies were demonstrated in all these rabbits. This reaction is induced by an accessory gland antigen identical or closely related to the autoantigen described by Shulman et al. (1966).

Other authors have failed to produce autoimmune testicular damage in rabbits. According to Weil \& Finkler (1959), the injection of seminal plasma or spermatozoa into rabbits (Dutch Belted) does not produce degenerative changes in the testes and epididymides of the treated animals although such material can produce a detectable response through serological reactions. The same authors mention a personal communication made by Bishop \& Katsh who stated that they also were unable to obtain degenerative changes in testes of rabbits injected with emulsions of testes in Freund's adjuvant. Weil concluded that the same changes that characterize the response of other mammals (rat and guinea-pig) are not produced in the testis and epididymis of the rabbit. Stevens \& Fost (1964) corroborated and expanded these results, claiming that prolonged immunization of rabbits with rabbit or human seminal plasma and/or spermatozoa in complete adjuvant neither depresses the sperm count nor produces testicular changes. In contrast to these findings, it has been shown in the present report that testicular lesions are consistently produced in rabbits by injection of rabbit seminal plasma. Although strain differences should be considered in the discussion, we believe that it is more important to stress the marked differences in the immunization schedules. The authors mentioned above used smaller total amounts of antigenic material than the 30 to $60 \mathrm{mg}$ of total protein used in the present work. In addition, the use of a supplementary amount of $M$. tuberculosis in the booster injection and the use of the intradermal route for injecting the material into several separate sites may have played a part in the potentiation of the antigenicity. 
Although allergic orchitis has been extensively studied in different mammals, a correlation between testicular lesions and semen characteristics has not been previously reported. A novel contribution of the present work is the result of the continuing study of the semen during the development of the immune lesion. It has been shown that neither the number nor the activity of the spermatozoa provide a true index of the nature or presence of a testicular lesion. This is in accordance with some observations made in human patients by Simmons (1952). On the other hand, the presence of many atypical spermatids and/or spermatocytes constitutes an unequivocal sign of a testicular lesion. We conclude that the spermiogram should be included in the techniques used for analysis of pathological behaviour and could be used to determine the appropriate moment for hemicastration.

The experimentally induced pathological condition developed in this work satisfies the definition of allergic orchitis. Therefore, using seminal plasma, it was possible to reproduce in rabbits the results obtained in other animals with testicular extract. Soluble antigens could be involved in the induction of this experimentally induced disease. It is important to relate this conclusion with the work of Vulchanov (1969), who was able to induce testicular damage by immunizing guinea-pigs with homologous seminal vesicular fluid. These facts lend support to the speculation of Toullet, Voisin \& Nemirovsky (1970) that the Arthus reaction and/or delayed hypersensitivity might be induced when soluble antigens released from spermatozoa gain access into the interstitium of the efferent ducts.

Results from serological tests indicate that a multiplicity of autoantigens are present in seminal plasma, a finding which is consistent with the reports of Voisin \& Toullet $(1968,1969)$ demonstrating the complex autoantigenic system present in guinea-pig spermatozoa. Even though the reaction of skin hypersensitivity suggests some correlation between delayed hypersensitivity and the development of the testicular lesion, complementary studies from our current investigation on the passive transfer of autoimmunity indicate that antibodies could also be operative in the development of testicular damage. This assumption is in close agreement with the hypothesis proposed and substantiated by Brown, Glynn \& Holborow (1967) and Toullet et al. (1970).

\section{ACKNOWLEDGMENTS}

We are indebted to Professor Sidney Shulman of the Department of Microbiology, New York Medical College, U.S.A., and Professor Roberto Mancini of the Centro de Investigaciones sobre Reproducción, Facultad de Medicina, Buenos Aires, Argentina, for the interest taken in this work and for helpful suggestions. Grateful acknowledgment is also made to Dr Clelia Riera, Dr Héctor Cámara and Miss Erika Baduy de Antun, for their help in the preparation of this paper.

\section{REFERENCES}

Andrada, J. A., Andrada, E. C. \& Witebsky, E. (1969) Experimental autoallergic orchitis in rhesus monkeys. Proc. Soc. exp. Biol. Med. 130, 1106. 
BoYden, S. V. (1951) The absorption of proteins on erythrocytes treated with tannic acid and subsequent hemagglutination by antiprotein sera. F. exp. Med. 93, 107.

Bredderman, P. J., Foote, R. H. \& Y Assen, A. M. (1964) An improved artificial vagina for collecting rabbit semen. 7. Reprod. Fert. 7, 401.

Brown, P. C., Grunn, L. E. \& Holborow, E. J. (1967) The dual necessity for delayed hypersensitivity and circulating antibody in the pathogenesis of experimental allergic orchitis in guinea-pigs. Immunology, 13, 307.

Campbell, D. H., Garvey, J. S., Gremer, N. E. \& Sussdorf, D. H. (1964) Methods in immunology, 2nd edn, p. 79. Benjamin, New York and Amsterdam.

Freund, J., Lipton, M. M. \& Thompson, G. E. (1953) Aspermatogenesis in the guinea-pig induced by testicular tissue and adjuvants. $\mathcal{F}$. exp. Med. 97, 711 .

Freund, J., Lipton, M. M. \& Thompson, G. E. (1954) Impairment of spermatogenesis in the rat after cutaneous injection of testicular suspension with complete adjuvants. Proc. Soc. exp. Biol. Med. 87, 408.

Kolmer, J. A. (1928) Serum diagnosis by complement fixation. Lea \& Febiger, Philadelphia. Reference in Kolmer, J. A., Spaulding, F. H. \& Robinson, H. W. (1955) Métodos de laboratorio, 5th edn, p. 793. Ed. Interamericana S.A. México.

Mancini, R. E., Andrada, J. A., Saraceni, D., Bachmann, A., Lavieri, J. C. \& Nemirovisky, M. (1965) Immunological and testicular response in man sensitized with human testicular homogenate. F. clin. Endocr. Metab. 25, 859.

Ouchterlony, O. (1958) Diffusion in gel methods for immunological analysis. Prog. Allergy, 5, 1.

Papanicolaou, G. N. (1954) Atlas of exfoliative cytology. Harvard University Press, Cambridge, Mass., U.S.A.

Pokorná, Z., Vojríšnová, M., Rychuíková, M. \& Chutná, J. (1963) An isologous model of experimental autoimmune aspermatogenesis in mice. Folia biol., Praha, 9, 203.

Shulman, S., Yantorno, C., Soanes, W. A., Gonder, M. J. \& Witebsky, E. (1966) Studies on organ specificity. XVI. Urogenital tissues and autoantibodies. Immunology, 10, 99.

Simmons, F. A. (1952) Correlation of testicular biopsy material with semen analysis in male infertility. Ann. N.Y. Acad. Sci. 55, 643.

Srevens, K. M. \& Fost, C. A. (1964) Sperm and antibody production in rabbits following immunization with sperm and semen. Proc. Soc. exp. Biol. Med. 117, 125.

Swierstra, E. E., Whitefield, J. W. \& Foote, R. H. (1964) Action of amphotericin B (Fungizone) on spermatogenesis in the rabbit. F. Reprod. Fert. 7, 13.

Toullet, F., Vorsin, G. A. \& NemirovsKy, M. (1970) Localisation cytologique et pouvoir pathogène des auto-antigènes de spermatozoïdes chez le cobaye. Annls Inst. Pasteur, Paris, 118, 513.

Vorsin, G. A., Delaunay, A. \& Barber, M. (1951) Sur des lésions testiculaires provoquées chez le cobaye par iso- et auto-sensibilisation. Annls Inst. Pasteur, Paris, 81, 48.

Vorsin, G. A. \& Toullet, F. (1968) Etude sur l'orchite aspermatogénétique autoimmune et les autoantigènes de spermatozoïdes chez le cobaye. Annls Inst. Pasteur, Paris, 114, 727.

Vorsin, G. A. \& Toullet, F. (1969) Studies on spermatozoa autoantigens in the guinea-pig. In: Int. Symp. on Immunology of Spermatozoa and Fertilization, Varna (Bulgarie). Bulgarian Academy of Sciences Press, edn 149.

Vulchanov, V. H. (1969) Testicular damage and autoantibody formation in guinea pigs immunized with homologous seminal vesicular fuid. In: Immunology and Reproduction, pp. 136-147. Ed. R. G. Edwards. International Planned Parenthood Federation, London.

Weil, A. J. \& Finkler, A. E. (1959) Isoantigenicity of rabbit semen. Proc. Soc. exp. Biol. Med. 102, 624.

WENTWORTh, B. C. \& MeLLen, W. J. (1964) Active immunity induced and spermatogenesis suppressed by testicular antigen in the male Japanese quail (Coturnix coturnix japonica). F. Reprod. Fert. 8, 215.

Yantorno, C., Soanes, W. A., Gonder, M. J. \& Shulman, S. (1967) Studies in cryo-immunology. I. The production of antibodies to urogenital tissue in consequence of freezing treatment. Immunology, 12, 395. 